\title{
Restoring ecosystem health to improve human health and well-being: physicians and restoration ecologists unite in a common cause
}

\author{
James C. Aronson $^{1,2}$, Charles M. Blatt ${ }^{3}$ and Thibaud B. Aronson ${ }^{1}$
}

\begin{abstract}
Many challenges we face today are intimately linked to and derive from the biophysical and ecological degradation underway in almost all ecosystems on Earth. Responding effectively will require (1) changes in our behavior as citizens, parents, and consumers, (2) a shift to more ecologically sound technologies, taxes, and laws, and (c) an increase in long-term investments in small-, medium-, and large-scale ecological restoration projects.

The health and integrity of terrestrial, coastal, and marine ecosystems directly affect human health in many ways, thus providing a powerful incentive for restoration. The recognition of the importance of biodiversity and ecosystem health in the daily lives of individuals is becoming more widespread, at least among scientists and policy makers, as is the drive to achieve widespread endorsement and participation at landscape/seascape, national, international, and planetary scales. However, to accelerate the process, the general public must be better informed and committed to participation. Ecosystem health is not a new idea but it is timely to revive discussion and expand the use of the concept in view of rapidly spreading national and international commitments to large-scale ecosystem restoration and healthy landscapes, e.g., at the UNFCCC COP (Convention of the Parties) in December 2015 in Paris, the UNCCD COP in October 2015, and the COP13 of the Conventions on Biological Diversity in December 2016.

When discussing restoration, the language of clinical medicine provides strong metaphors that may be useful for communication, education, research, lobbying, and outreach. Because of the links between ecosystem health and human health, physicians and health care workers in general have an important role to play alongside restoration scientists and practitioners. Furthermore, insight from the fields of clinical medical practice, research, and public health could also provide lessons for ecosystem restoration practitioners. Together, the two groups could form a potent interdisciplinary team. The authors, two ecologists and a physician, explore the use of ecosystem health as a metaphor related to human health and discuss the growing evidence of direct and indirect impacts of ecosystem dysfunction on human health.
\end{abstract}

Key Words: ecological restoration; ecosystem health; human health; natural capital; metaphors; restoration culture; social capital; wellbeing

\section{INTRODUCTION}

In December 2015, the 21st Conference of the Parties of the UN Framework Convention on Climate Change met in Paris and agreed to an historic agreement to reduce greenhouse gas emissions that pollute our biosphere. Achieving this goal in a timely fashion will clearly require the adoption of new paradigms for land, water, and resource use, avoidance of further degradation of ecosystems, and the expansion of major ecological restoration efforts at landscape and regional scales.

Societal shifts are also needed in three areas: (1) more enlightened behavior as citizens, parents, and consumer, (2) technologies that are more ecologically sound and sustainable, and (3) vastly greater investment in large-scale restoration of degraded ecosystems (Blignaut et al. 2014). This would mark a transition to what we suggest to call a "restoration culture" for the 21 st century (Barton 2009, Aronson and Alexander 2013, UNCCD 2015). However, we stress that the rapidly growing science and technology available to help restore and rehabilitate damaged, degraded, or destroyed ecosystems must never be accepted as a substitute or surrogate for conservation or a "license to trash" in the name of short-term profits in financial capital.

In general terms, many people know that the health of the biosphere is declining, but commitment to actually alter human practices to reduce our collective ecological footprint is weak (Dunlap 1991). This weakness could be addressed by increasing awareness among the general public of the range of options available to actually halt and reverse degradation. Ecological restoration is prominent among these options, and it is now recognized as one of the U.N. Sustainability Development Goals (U.N. 2015). Commitments and good intentions, e.g., in 6 countries of Latin America (http://blog.cifor.org/25807/latinamerican-countries-pledge-to-restore-20-million-ha-of-degradedland?fnl=en) and 10 countries in Africa (http://www.cp-africa. com/2015/12/07/10-african-couce-the-afr-100/) must be translated now into action with willing and qualified workers on the job.

We suggest that physicians and all those who work in the public health and medical sectors could help significantly in the education and communication campaigns that are underway. On the one hand, the language of medicine offers a potent metaphor for ecological restoration (Harris and Hobbs 2001) that could help emphasize its promise for human welfare and the transition to sustainability. On the other, health care practitioners can speak directly to their patients as trusted caregivers, and transmit the message of the benefits of a healthier environment in ways that ecologists, for example, often cannot.

One way to jumpstart such a dialogue is to agree on a set of terms that will allow us to discuss ecosystem illnesses and trauma and their corresponding treatments in a professional and transdisciplinary fashion. In Box 1, we define some key terms in medicine, restoration ecology, and ecological economics,

${ }^{1}$ Missouri Botanical Garden, St. Louis, MO, USA, ${ }^{2}$ Centre d'Ecologie Fonctionnelle et Evolutive, Montpellier, France, ${ }^{3}$ Lown Cardiovascular Group, Brigham and Women's Hospital and Harvard Medical School, Chestnut Hill, MA, USA 
including four metaphors: ecosystem health, natural capital, ecosystem services, and healthy landscapes. In addition, we shall present a comparative table, and a schematic model comparing the trajectory of an ecosystem and that of a human life including a period of trauma and recovery from it. Our goal is to illustrate the strong conceptual and practical links, albeit at different scales, between the science and practice of clinical medicine and ecological restoration. We build this discussion on the fact that we are a restoration ecologist (JA), a conservation ecologist with special interest in animal behavior (TBA), and, a physician (CMB), with 30 years of experience in clinical cardiology practice and research.

\section{Box 1: Definitions for a transdisciplinary dialogue}

Ecological restoration: "the process of assisting the recovery of an ecosystem that has been degraded, damaged, or destroyed" (SER 2004:3, Clewell and Aronson 2013). Cf. restoring natural capital. Note that social capital is enhanced when people work together for ecological restoration and restoring natural capital.

Human health: "a state of complete physical, mental, and social well-being and not merely the absence of disease or infirmity" (WHO 1948).

Human well-being: "Has several key components: the basic material needs for a good life,... health, good social relations, and personal security" (MEA 2005a:71).

Ecological footprint: A concept and calculation method developed and launched by Wackernagel and Rees (1997) to analyze and compare human impacts on ecosystems with respect to their and the biosphere's ability to regenerate resources and provide goods and services.

Ecosystem health: "An ecological system is healthy and free from 'distress syndrome' if it is... active and maintains its organization and autonomy over time and is resilient to stress" Haskell et al. (1992:9, see also Ford et al. 2015)

Some regard the concept of ecosystem health as problematic given that it is difficult to measure and can only be meaningfully assessed over long periods of time (Suter 1993, Rapport et al. 1998). Certainly characterization and measurement of both terms require subjective as well as objective human judgements. We argue, however, that it remains a highly useful metaphorical tool for communication and consensus building (Grifo and Rosenthal 1997).

Ecosystem goods and services: "the direct and indirect contributions of ecosystems to human wellbeing" (de Groot et al. 2010:12, emphasis added). Often shortened to ecosystem services (ES). ES are made possible thanks to ecosystem functions and the still deeper ecosystem processes and structure. The Millennium Ecosystem Assessment (2005b) recognized four categories of ES, namely, supporting, regulating, provisioning, and cultural. Others, such as The Economics of Ecosystems and Biodiversity Project, consider that ES serve all species, not just humans, and therefore also recognize "habitat services" (de Groot et al. 2010).

Healthy landscape: a landscape that is integrated and multifunctional both in ecological and cultural terms.
Increasingly it is recognized that to be truly effective, both ecosystem restoration and restoring natural capital should be planned and managed with a landscape approach where a system is degraded (e.g., Crossman and Bryan 2009).

Landscape approach: "a framework to integrate policy and practice for multiple competing land uses through the implementation of adaptive and integrated management systems" (Reed et al. 2016:2544; cf. Reed et al. 2015).

Natural capital: a metaphor borrowed from economics to denote the limited stocks of physical and biological natural elements found on Earth, some of which are of direct use to human society (then called resources) and others that are not (de Groot et al. 2010).

Restoring natural capital: consists of four elements: ecological restoration of degraded ecosystems; reducing the negative impact of production systems (farming, etc.); reducing negative impact of cities, resource extraction, and transport; and education, communication, and outreach to increase awareness of the importance of natural capital and ecosystem services in our everyday lives (Aronson et al. 2007). Of the four types recognized (MEA 2005b), renewable natural capital (i.e., natural and semicultural ecosystems and their native biodiversity), and cultivated natural capital (i.e., traditional crop varieties and races of livestock, and traditional agro-ecological knowledge) are the most relevant here (Neßhöver et al. 2011).

Social capital: institutions, relationships, social networks, and shared cultural beliefs and traditions that promote mutual trust and willingness among people to work together for common goals. Restoring natural capital requires a concomitant process of restoring social capital.

\section{ECOSYSTEM HEALTH, NATURAL CAPITAL, ECOSYSTEM SERVICES, AND HEALTHY LANDSCAPES}

The concept of ecosystem health as related to description and norms for nature conservation goes back to the land health metaphor of Aldo Leopold (1949; see Callicott 1992, Meine 2004), among many other sources. Much more on this concept was published in the 1990s, in the Journal of Aquatic Ecosystem Health (e.g., Kolasa and Pickett 1992), Ecosystem Health (e.g., Rapport et al. 1999), and Conservation Ecology, the precursor to Ecology and Society (e.g., Janssen 2001, Levin 2001, Walker 2001). In addition, a strong argument that Leopold's metaphor could and should be applied to environmental and ecosystem planning, as well as management in general was made by Costanza, Norton, and Haskell (1992) and developed further by Grifo and Rosenthal (1997). Today, "ecosystem health" is widely accepted as a better term than land health, but the meaning is much the same.

Also in the 1990s, the concept of natural capital gained traction (Costanza and Daly 1992, Costanza et al. 1997) and this helped bring attention to rapidly increasing human influence and reliance on ecosystem goods and services. Chichilnilsky and Heal (2001) edited the volume Managing Human-Dominated Ecosystems, which, followed by the Millennium Ecosystem Assessment $(2005 a, b)$, helped set up a tipping point in public awareness, especially among policy makers and the science and environment 
media. The Economics of Ecosystems and Biodiversity (TEEB), whose reports began to appear in 2010, pushed the process another large step forward (ten Brink 2011).

Concurrently, the science, business, practice, and self-organizing social movement of ecological restoration took form in the late 1980s (Jordan and Lubick 2011, Woodworth 2013). Yet it has only recently figured prominently on international political agendas, especially since the ratification of the Aichi Biodiversity targets at the COP21 of the Conventions on Biological Diversity (CBD) in December 2012 (Aronson and Alexander 2013). However, there are still major gaps between science and policy, and between both of them and public engagement.

To move a step further, and develop more than a movement but an actual "restoration culture," the concept of restoration of natural capital (Aronson et al. 2007) and that of ecosystem services are vitally important as well (de Groot et al. 2002, 2010, MEA 2005a), given that both can help build bridges between economics, ethics, and restoration ecology.

\section{PARALLELS BETWEEN CLINICAL MEDICINE AND ECOLOGICAL RESTORATION}

In this section, we seek to illustrate the compelling links and analogies between ecological restoration and clinical medicine. These can help make the concepts of ecosystem health, restoring natural capital, and large-scale ecosystem restoration, and their positive impacts on human health, more widely accessible and help the effort to mainstream them into national policies and international law. First, let us consider the issues, drivers, and actors in ecosystem health and human health (Table 1).

Table 1. Issues, drivers, and actors in ecosystem health and human health.

\begin{tabular}{|c|c|c|}
\hline $\begin{array}{l}\text { Issues, Drivers, } \\
\text { Actors }\end{array}$ & $\begin{array}{l}\text { Ecosystems and native } \\
\text { biodiversity }\end{array}$ & $\begin{array}{l}\text { Individual humans and } \\
\text { communities }\end{array}$ \\
\hline Current state & $\begin{array}{l}\text { Most ecosystems } \\
\text { degraded to some degree, } \\
\text { damaged or destroyed } \\
\text { (i.e., following mining) }\end{array}$ & $\begin{array}{l}\text { Ill patients, poor public } \\
\text { health, declining hope, } \\
\text { cooperation, and social } \\
\text { integrity in most cultures }\end{array}$ \\
\hline The problem & $\begin{array}{l}\text { Dysfunction, biological } \\
\text { impoverishment, loss of } \\
\text { connectivity and } \\
\text { resilience }\end{array}$ & $\begin{array}{l}\text { Infectious diseases, } \\
\text { environmentally caused } \\
\text { illnesses, malnutrition, } \\
\text { depression, and impaired } \\
\text { immune defenses }\end{array}$ \\
\hline Goals & $\begin{array}{l}\text { To maintain and restore } \\
\text { resilient and healthy } \\
\text { habitat for native biota, } \\
\text { within self-sustainable, } \\
\text { healthy, and } \\
\text { interconnected } \\
\text { ecosystems }\end{array}$ & $\begin{array}{l}\text { To treat and maintain } \\
\text { health in individuals and } \\
\text { communities; to enhance } \\
\text { resistance to diseases; to } \\
\text { reduce environmental } \\
\text { risks to settlements and } \\
\text { communities }\end{array}$ \\
\hline $\begin{array}{l}\text { Diagnosticians, } \\
\text { caregivers }\end{array}$ & $\begin{array}{l}\text { Restoration ecologists, } \\
\text { land and water engineers, } \\
\text { managers, direct users, } \\
\text { including farmers and } \\
\text { citizen volunteers }\end{array}$ & $\begin{array}{l}\text { Health care providers, } \\
\text { public health specialists }\end{array}$ \\
\hline
\end{tabular}

There are obvious differences, but of particular interest to us are the similarities between ecological restoration and human medicine. In Figure 1, we offer a schematic diagram that compares the main phases and events of ecosystem health with human health at individual and population levels. Inherent differences in temporal and spatial scales are obvious, but should not affect the value of the figure to promote discussion and new thinking.

Within this comparative framework, a healthy human is able to carry out all aspects of daily living without impediment. Although often subject to minor stresses, such as colds and bruises, a healthy person's immune system, and natural regenerative capability, enable rapid and full recovery without external care. Likewise, a healthy ecosystem shows unimpaired biotic as well as abiotic processes and a complete "web of life" capable of adapting to changing global and local conditions. Small disturbances, such as localized fires and floods are common but do not cause lasting harm to the ecosystem; in fact they are often an integral part of ecosystems, as part of long-established disturbance regimes. However, it must be noted that, because of the large number of internal and external drivers and stressors associated with ecosystems, a healthy ecosystem's state over a long period of time is in general not fixed, but rather oscillates within a range of historical variability (Higgs 1997) or "historical environmental variation" (Wiens et al. 2012).

At some point in their lives, many humans suffer a trauma or an illness too serious for them to recover from on their own, and a medical intervention becomes necessary. In some cases, correcting or removing the stressing factor will be enough (setting a broken leg, eliminating infectious agents, etc.); in others, physicians will replace what has been lost or degraded (blood transfusion, organ transplant, etc.). At the level of communities, public health interventions tend to focus on eliminating contaminants in air or water, and identify the source, and control the spread of infectious diseases such as HIV/AIDS and Ebola.

Similarly, even in highly resilient ecosystems, when degradation is severe, or prolonged, or both, the system may be unable to fully recover on its own. This is when restoration practitioners step in. In some cases, it may be sufficient to remove the causes of degradation (overgrazing, eutrophication, unsustainable logging, invasive species, etc.) to enable the ecosystem to recover (natural regeneration) to its historical trajectory or historical range of variability. In other instances, further actions may be necessary (replanting native plant species, reintroducing locally extinct animal species, etc.). In the case of ecosystems with very long histories of human presence and management, other dimensions must be taken into account, and reinstatement or proxies of former traditional activities by local people may be required; still, the same analogies and the language of human health can be applied.

One important difference between humans and ecosystems, as mentioned above, is that their life spans are on radically different scales, and healthy ecosystems usually looked and functioned differently at different periods of time in the past. Therefore, there can be several valid "ecosystems of reference" that ecological restoration practitioners and stakeholders may choose from to orient and guide the process of restoring a damaged ecosystem (Aronson et al. 1993, SER 2004). In light of anthropogenic climate change, and other major global changes, the appropriate goals for ecological restoration should therefore be restoring fundamental functions and processes (Falk et al. 2006), and recovering "historical continuity" (Clewell and Aronson 2013) so as to increase an ecosystem's resilience and ability to adapt to 
Fig. 1. Ecosystem health (black type) and human health (blue type) expressed as trajectories over time. The fourpointed star symbol represents a perturbation, whereas the upward-pointing arrow represents regeneration. Black symbols represent minor phenomena, which happen and are dealt with within the system. Colored symbols represent both severe disturbances (in red) that affect normal functioning of the system, and the external interventions (in green) that are required to return to a baseline (i.e., healthy) state.

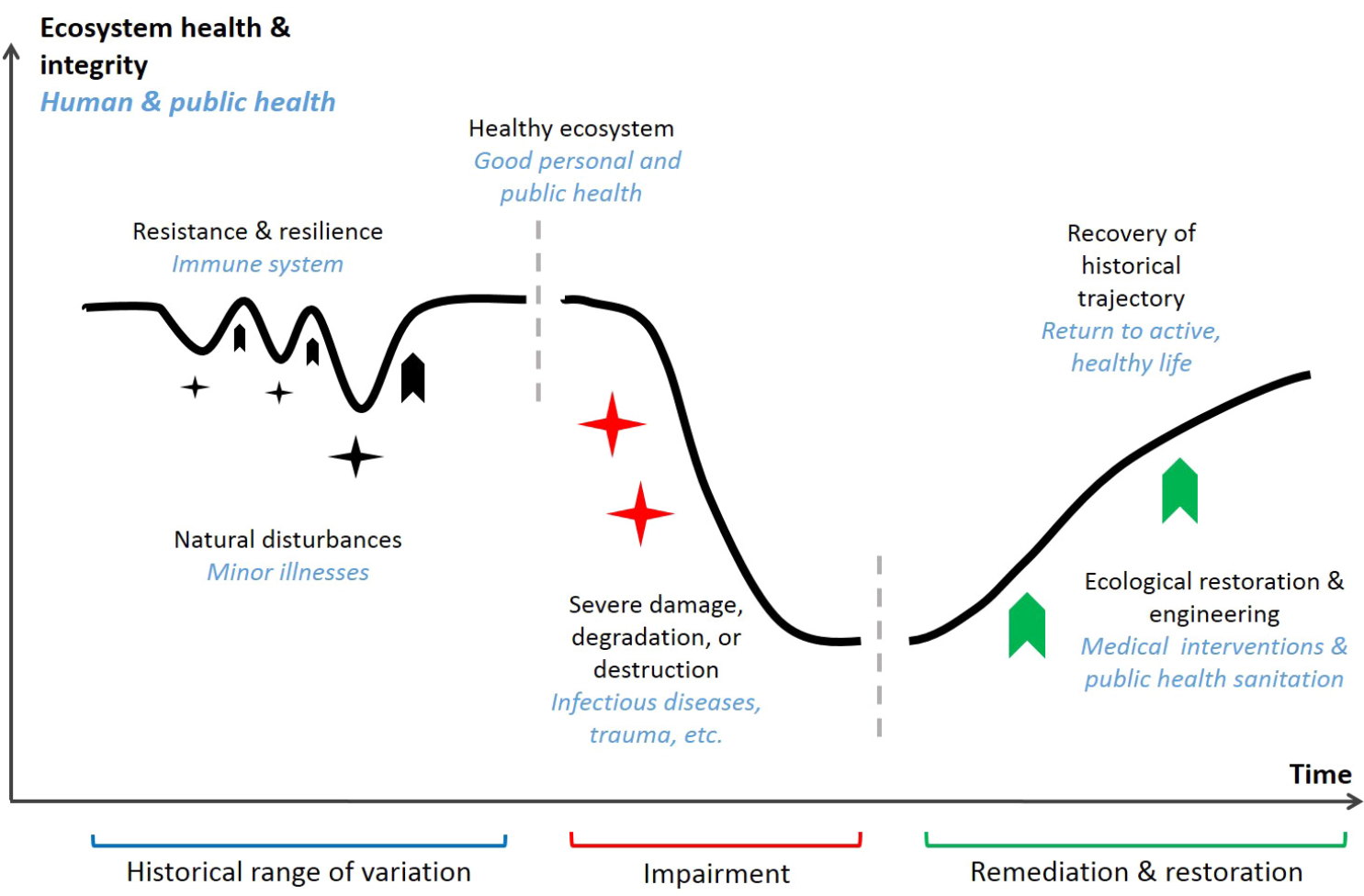

future change. But health metaphors and analogies are still very helpful in considering and communicating these goals.

In addition to the conceptual analogy spelled out above, there is a very concrete link between human health and ecosystem health, which may draw the attention and engagement of the medical community. Indeed, damaged and polluted ecosystems cause profound impairment of human health, as we discuss in further detail below.

\section{WHY SHOULD PHYSICIANS AND HEALTH CARE WORKERS GET INVOLVED?}

In the decade since the Millennium Ecosystem Assessment (MEA $2005 c$ ) was published, the links between ecosystem health and human health have been widely acknowledged. Considering the planetary scale of ecosystem degradation, it is likely that the health and well-being of most, if not all humans, is negatively affected by ecosystem degradation in at least some way (Myers et al. 2013, Redford et al. 2014). Recently, both the WHO (2015) and the journal Lancet commissioned reports (Costello et al. 2009, Whitmee et al. 2015) that synthesize our knowledge base and make strong calls to action on anthropogenic climate change and other human-mediated drivers of environmental degradation. And yet, none of the above-cited studies provides a roadmap to slow or reverse the degradation of ecosystems worldwide, such as large-scale ecological restoration.
Many, including Pope Francis, argue it has now become a matter of fundamental ethics to change course (Raven 2016), arguably along the lines cited at the outset of this paper: the three societal shifts described by Blignaut and coworkers (2014). Clearly, environmental education is vital as well, and it is now urgent to communicate, and demonstrate, how ecological restoration work actively addresses, and redresses, environmental "illnesses." We must also continue to study and communicate the myriad ways in which healthy ecosystems benefit human health and well-being (van den Bosch and Depledge 2015). These include the following:

1. Reduction of disease incidence: For instance, one of the key health issues of the 21 st century is emerging infectious diseases, $75 \%$ of which are zoonoses (Taylor et al. 2001, Keesing et al. 2010). Healthy ecosystems, supporting diverse animal communities, provide a dilution effect, reducing through competition the number of hosts for vector-borne diseases. Moreover, it appears that in degraded environments, the animal species that are able to persist because of traits such as high metabolism and fast reproductive rates, are often better hosts for vector-borne diseases because of these same traits (Keesing et al. 2010).

2. Protection from natural disasters: An example is coastal barrier systems, such as mangrove forests and coral reefs that provide protection from extreme weather events to coastal populations, which constitute about a third of 
humanity (Danielsen et al. 2005, Barbier et al. 2008). Besides the loss of lives, natural disasters are often followed by significant public health crises (Noji 2005).

3. Provision of basic goods and services necessary for human survival: An example is the insect species that act as pollinators for many staple crops (Buchmann and Nabhan 1997). The worldwide decline of bees and other pollinator species, through excessive use of pesticides, puts in jeopardy a third of humanity's food crops. Additionally, intact forest ecosystems, acting as filters and topsoil protectors, help maintain clean water and clean air for human populations (Powe and Willis 2004, Brauman et al. 2007).

4. Psychological well-being: It has been shown that urban nature has important physiological, social, and psychological benefits for people (Chiesura 2004, Bratman et al. 2012, Elmqvist et al. 2015). The duration of hospitalization following common abdominal surgical procedures was shown to be shorter when patients had a view of natural greenery vs. a brick wall from their hospital window (Ulrich et al. 1991, Bolund and Hunhammar 1999).

Moreover, when people work together on ecological restoration projects, it helps restore social capital, which in turn has repeatedly been shown to have very positive effects on local communities and, by extension, on public health. Many examples of this, from six continents, are described in Woodworth (2013).

\section{WHAT'S THE NEXT STEP?}

Medical research and clinical practice have revealed that there are "miniature" ecosystems that exist within human bodies, the deterioration of which is the cause of many serious health problems. For instance, disruption of intestinal bacterial flora can give rise to potentially life-threatening Clostridium difficile infections (Britton and Young 2014). Reducing the use of unnecessary antibiotics or taking measures to restore the diversity and stability of intestinal flora may substantially reduce the incidence of such infections.

However, just as there are ecosystems within our bodies, humans are equally embedded in much larger social-ecological systems, the condition of which have direct impacts on our health and general well-being. So, what's next?

The science and practice of ecosystem restoration are prominent in the recent Calls of the United Nations CBD, (2012) and the UN Convention on Combating Desertification (UNCCD 2015). The EU has called explicitly for large scale restoration interventions and paradigm shifts (Lammerant et al. 2014). However, at present, in most ecosystem types, our ability to recover biodiversity and ecosystem functions is not perfect (Ballantine and Schneider 2009, Bullock et al. 2011, Kovalenko et al. 2013). Even in extra-tropical wetlands, where large numbers of restoration projects have taken place over the last 30 years, we are only achieving approximately $70 \%$ of predegradation benchmarks, in terms of both biodiversity and ecosystem functioning (Moreno-Mateos et al. 2012). Increased funding is needed for science and technology, and for professional training and capacity-building.

As we have discussed, the conceptual similarities between the approaches of human medicine and ecological restoration can help make the concept more accessible to the general public. By helping communicate and interpret in palatable language the direct benefits of ecological restoration for human health, physicians and the public health care workforce can bring powerful voices to the ecological restoration movement to accelerate the urgently needed ecological restoration activities and place them in the mainstream of political, social, and economic policy discussions.

We take as an example the International Physicians for the Prevention of Nuclear War for which its founders were honored with the Nobel Peace Prize in 1985 (IPPNW 1991). In launching that movement in 1980, prominent physicians from both sides of the Cold War front brought their concerns about the risks posed by nuclear arms to the health and well-being of humanity to the attention of the public. By 1985, the IPPNW represented 135,000 physicians from 41 nations. The fight for nuclear disarmament is far from finished but, in the meantime, other ecological disasters and risks affect our biosphere.

We suggest that the formation of a coalition consisting of those working for ecological restoration and healthy landscapes, on the one hand, and physicians and public health workers on the other, could be very helpful in communicating the urgent need for global restoration and transforming that awareness into effective action. Our task would be to undertake a campaign similar to that of the IPPNW, which is still confronting the ongoing risk of nuclear war (Helfand and Sidel 2015). This new campaign would call for the defense of both human health and ecosystem health as a single integrated goal.

Indeed, without significant investment in restoring health to degraded and impaired ecosystems at all spatial scales, we will continue to see a decline in the quality and diversity of ecosystem functioning and services, and a corresponding decline in human health. That is quite clear; business as usual is no longer an option.

One promising start is the Future Earth project of the ecoHEALTH coalition (Machalaba et al. 2015), driven by scientists and practitioners from the ecological, medical, and sustainability fields to address the links between environmental health and global human health. One key gap in their toolbox, however, is ecological restoration. We would therefore suggest to go even further: to communicate and work together across all disciplinary boundaries to communicate and train people more widely regarding the real option of ecological restoration at ecosystem and landscape scales.

As mentioned above, the UN has been at the forefront of providing an internationally agreed framework for action on linking ecosystem restoration to maintaining biodiversity with a landscape approach that truly integrates local people (Janishevski et al. 2015). This vision will hopefully be pushed further toward mainstreaming at the upcoming COP13 of the CBD, where the theme of ecological restoration and "healthy landscapes" will be very prominent in the discussions. Active participation of the public is a sine qua non for a real transition and lasting paradigm shift toward a restoration culture mindful of both human and ecosystem health. We invite ecological restoration and medical practitioners to contact us with a view to building a campaign for the restoration of human and ecosystem health. 
Responses to this article can be read online at: http://www.ecologyandsociety.org/issues/responses. php/8974

\section{Acknowledgments:}

We warmly thank Paddy Woodworth, Larry Benowitz, Sasha Alexander, Curt Meine, Carolina Murcia, Anne Tolvanen, and two anonymous reviewers for their insightful and helpful comments on earlier versions of the manuscript.

\section{LITERATURE CITED}

Aronson, J., and S. Alexander. 2013. Ecosystem restoration is now a global priority: time to roll up our sleeves. Restoration Ecology 21:293-296. http://dx.doi.org/10.1111/rec.12011

Aronson, J., C. Floret, E. Le Floc'h, C. Ovalle, and R. Pontanier. 1993. Restoration and rehabilitation of degraded ecosystems in arid and semi-arid lands. I. A view from the south. Restoration Ecology 1:8-17. http://dx.doi.org/10.1111/j.1526-100X.1993. $\underline{\text { tb00004.x }}$

Aronson, J., S. J. Milton, and J. N. Blignaut, editors. 2007. Restoring natural capital: science, business, and practice. Island Press, Washington, D.C., USA.

Ballantine, K., and R. Schneider. 2009. Fifty-five years of soil development in restored freshwater depressional wetlands. Ecological Applications 19:1467-1480. http://dx.doi.org/10.1890/07-0588.1

Barbier, E. B., E. W. Koch, B. R. Silliman, S. D. Hacker, E. Wolanski, J. Primavera, E. F. Granek, S. Polasky, S. Aswani, L. A. Cramer, D. M. Stoms, C. J. Kennedy, D. Bael, C. V. Kappel, G. M. E. Perillo, and D. J. Reed. 2008. Coastal ecosystem-based management with nonlinear ecological functions and values. Science 319:321-323. http://dx.doi.org/10.1126/science.1150349

Barton, H. 2009. Land use planning and health and well-being. Land Use Policy 26(Supplement 1):S115-S123. http://dx.doi. org/10.1016/j.landusepol.2009.09.008

Blignaut, J., J. Aronson, and R. de Groot. 2014. Restoration of natural capital: a key strategy on the path to sustainability. Ecological Engineering: Sustainable Restoration 65:54-61. http:// dx.doi.org/10.1016/j.ecoleng.2013.09.003

Bolund, P., and S. Hunhammar. 1999. Ecosystem services in urban areas. Ecological Economics 29:293-301. http://dx.doi. org/10.1016/S0921-8009(99)00013-0

Bratman, G. N., J. P. Hamilton, and G. C. Daily. 2012. The impacts of nature experience on human cognitive function and mental health. Annals of the New York Academy of Sciences 1249:118-136. http://dx.doi.org/10.1111/j.1749-6632.2011.06400. $\underline{\mathrm{X}}$

Brauman, K. A., G. C. Daily, T. K. Duarte, and H. A. Mooney. 2007. The nature and value of ecosystem services: an overview highlighting hydrologic services. Annual Review of Environment and Resources 32:67-98. http://dx.doi.org/10.1146/annurev. energy.32.031306.102758

Britton, R. A., and V. B. Young. 2014. Role of the intestinal microbiota in resistance to colonization by Clostridium difficile.
Gastroenterology 146:1547-1553. http://dx.doi.org/10.1053/j. gastro.2014.01.059

Buchmann, S. L., and G. P. Nabhan. 1997. The forgotten pollinators. Island Press, Washington, D.C., USA.

Bullock, J. M., J. Aronson, A. C. Newton, R. F. Pywell, and J. M. Rey-Benayas. 2011. Restoration of ecosystem services and biodiversity: conflicts and opportunities. Trends in Ecology \& Evolution 26:541-549. http://dx.doi.org/10.1016/j.tree.2011.06.011

Callicott, J. B. 1992. Aldo Leopold's metaphor. Pages 42-56 in R. Costanza, B. G. Norton, and B. D. Haskell, editors. Ecosystem health: new goals for environmental management. Island Press, Washington, D.C., USA.

Chichilnilsky, G., and G. Heal, editors. 2001. Managing humandominated ecosystems: proceedings of the symposium at the Missouri Botanical Garden, St. Louis, Missouri, 26-29 March 1998. Missouri Botanical Garden Press, St. Louis, Missouri, USA.

Chiesura, A. 2004. The role of urban parks for the sustainable city. Landscape and Urban Planning 68:129-138. http://dx.doi. org/10.1016/j.landurbplan.2003.08.003

Clewell, A. F., and J. Aronson. 2013. Ecological restoration: principles, values, and structure of an emerging profession. Second edition. Island Press, Washington, D.C., USA. http://dx.doi. org/10.5822/978-1-59726-323-8

Convention on Biological Diversity. 2012. UNEP/CBD/COP Decision XI/16. Ecosystem restoration. Convention on Biological Diversity, Hyderabad, India. [online] URL: http://www.cbd.int/ doc/decisions/cop-11/cop-11-dec-16-en.pdf

Costanza, R., and H. E. Daly. 1992. Natural capital and sustainable development. Conservation Biology 6:37-46. http://dx. doi.org/10.1046/j.1523-1739.1992.610037.x

Costanza, R., R. d'Arge, R. de Groot, S. Farber, M. Grasso, B. Hannon, K. Limburg, S. Naeem, R. V. O’Neill, J. Paruelo, R. G. Raskin, P. Sutton, and M. van den Belt. 1997. The value of the world's ecosystem services and natural capital. Nature 387:253-260. http://dx.doi.org/10.1038/387253a0

Costanza, R., B. G. Norton, B. D. Haskell, editors. 1992. Ecosystem health: new goals for environmental management. Island Press, Washington, D.C., USA.

Costello, A., M. Abbas, A. Allen, S. Ball, S. Bell, R. Bellamy, S. Friel, N. Groce, A. Johnson, M. Kett, M. Lee, C. Levy, M. Maslin, D. McCoy, B. McGuire, H. Montgomery, D. Napier, C. Pagel, J. Patel, J. A. P. de Oliveira, N. Redclift, H. Rees, D. Rogger, J. Scott, J. Stephenson, J. Twigg, J. Wolff, and C. Patterson. 2009. Managing the health effects of climate change. Lancet 373:1693-1733. http://dx.doi.org/10.1016/S0140-6736(09)60935-1

Crossman, N. D., and B. A. Bryan. 2009. Identifying cost-effective hotspots for restoring natural capital and enhancing landscape multifunctionality. Ecological Economics 68:654-668. http://dx. doi.org/10.1016/j.ecolecon.2008.05.003

Danielsen, F., M. K. Sørensen, M. F. Olwig, V. Selvam, F. Parish, N. D. Burgess, T. Hiraishi, V. M. Karunagaran, M. S. Rasmussen, L. B. Hansen, A. Quarto, and N. Suryadiputra. 2005. The Asian tsunami: a protective role for coastal vegetation. Science 310:643. http://dx.doi.org/10.1126/science.1118387 
de Groot, R., B. Fisher, M. Christie, J. Aronson, L. Braat, R. Haines-Young, J. Gowdy, E. Maltby, A. Neuville, and S. Polasky. 2010. Integrating the ecological and economic dimensions in biodiversity and ecosystem service valuation. Pages 9-40 in K. Pushpam, editor. The economics of ecosystems and biodiversity (TEEB): ecological and economic foundations. Earthscan, London, UK.

de Groot, R. S., M. A. Wilson, and R. M. J. Boumans. 2002. A typology for the classification, description and valuation of ecosystem functions, goods and services. Ecological Economics 41:393-408. http://dx.doi.org/10.1016/S0921-8009(02)00089-7

Dunlap, R. E. 1991. Public opinion in the 1980s clear consensus, ambiguous commitment. Environment: Science and Policy for Sustainable Development 33:10-37. http://dx.doi.

org/10.1080/00139157.1991.9931411

Elmqvist, T., H. Setälä, S. N. Handel, S. van der Ploeg, J. Aronson, J. N. Blignaut, E. Gómez-Baggethun, D. J. Nowak, J. Kronenberg, and R. de Groot. 2015. Benefits of restoring ecosystem services in urban areas. Current Opinion in Environmental Sustainability 14:101-108. http://dx.doi.org/10.1016/j.cosust.2015.05.001

Falk, D. A., M. A. Palmer, and J. B. Zedler, editors. 2006. Foundations of restoration ecology. Island Press, Washington, D. C., USA.

Ford, A. E. S., H. Graham, and P. C. L. White. 2015. Integrating human and ecosystem health through ecosystem services frameworks. EcoHealth 12:660-671. http://dx.doi.org/10.1007/ s10393-015-1041-4

Grifo, F., and J. Rosenthal, editors. 1997. Biodiversity and human health. Island Press, Washington, D.C., USA.

Harris, J. A., and R. J. Hobbs. 2001. Clinical practice for ecosystem health: the role of ecological restoration. Ecosystem Health 7:195-202. http://dx.doi.org/10.1046/j.1526-0992.2001.01041.x

Haskell, B. D., B. G. Norton, and R. Costanza. 1992. Introduction: What is ecosystem health and why should we worry about it? Pages 3-20 in R. Costanza, B. G. Norton, and B. D. Haskell, editors. Ecosystem health: new goals for environmental management. Island Press, Washington, D.C., USA.

Helfand, I., and V. W. Sidel. 2015. Docs and nukes - still a live issue. New England Journal of Medicine 373:1901-1903. http://dx. doi.org/10.1056/NEJMp1509202

Higgs, E. S. 1997. What is good ecological restoration? Conservation Biology 11:338-348. http://dx.doi.org/10.1046/ j.1523-1739.1997.95311.x

International Physicians for the Prevention of Nuclear War (IPPNW). 1991. Radioactive heaven and earth: the health and environmental effects of nuclear weapons testing in, on, and above the earth: a report of the IPPNW International Commission to Investigate the Health and Environmental Effects of Nuclear Weapons Production, and the Institute for Energy and Environmental Research. Apex Press, New York, New York, USA.

Janishevski, L., C. Santamaria, S. Gidda, D. Cooper, and P. Brancalion. 2015. Ecosystem restoration, protected areas and biodiversity conservation. Unasylva 245:19-27.
Janssen, M. A. 2001. An immune system perspective on ecosystem management. Conservation Ecology 5(1):13. http://dx.doi. org/10.5751/es-00242-050113

Jordan III, W. R., and G. M. Lubick. 2011. Making nature whole: a history of ecological restoration. Island Press, Washington, D. C., USA. http://dx.doi.org/10.5822/978-1-61091-042-2

Keesing, F., L. K. Belden, P. Daszak, A. Dobson, C. D. Harvell, R. D. Holt, P. Hudson, A. Jolles, K. E. Jones, C. E. Mitchell, S. S. Myers, T. Bogich, and R. S. Ostfeld. 2010. Impacts of biodiversity on the emergence and transmission of infectious diseases. Nature 468:647-652. http://dx.doi.org/10.1038/nature09575

Kolasa, J., and S. T. A. Pickett. 1992. Ecosystem stress and health: an expansion of the conceptual basis. Journal of Aquatic Ecosystem Health 1:7-13. http://dx.doi.org/10.1007/BF00044404

Kovalenko, K. E., J. J. H. Ciborowski, C. Daly, D. G. Dixon, A. J. Farwell, A. L. Foote, K. R. Frederick, J. M. G. Costa, K. Kennedy, K. Liber, M. C. Roy, C. A. Slama, and J. E. G. Smits. 2013. Food web structure in oil sands reclaimed wetlands. Ecological Applications 23:1048-1060. http://dx.doi.org/10.1890/12-1279.1

Lammerant, J., R. Peters, M. Snethlage, B. Delbaere, I. Dickie, and G. Whiteley. 2014. Implementation of 2020 EU Biodiversity Strategy: priorities for the restoration of ecosystems and their services in the EU. Report to the European Commission. ARCADIS, Ghent, Belgium. [online] URL: http://ec.europa.eu/ environment/nature/biodiversity/comm2006/pdf/2020/RPF.pdf

Leopold, A. 1949. A Sand County almanac and sketches here and there. Oxford University Press, New York, New York, USA.

Levin, S. A. 2001. Immune systems and ecosystems. Conservation Ecology 5(1):17. http://dx.doi.org/10.5751/es-00232-050117

Machalaba, C. C., P. Daszak, W. B. Karesh, and P. Shrivastava. 2015. Future Earth and ecohealth: a new paradigm toward global sustainability and health. EcoHealth 12:553-554. http://dx.doi. org/10.1007/s10393-015-1076-6

Millennium Ecosystem Assessment (MEA). 2005a. Ecosystems andhuman well-being: general synthesis. Island Press, Washington, D.C., USA.

Millennium Ecosystem Assessment (MEA). 2005b. Ecosystems and human well-being: current state and trends. Island Press, Washington, D.C., USA.

Millennium Ecosystem Assessment (MEA). 2005c. Ecosystems and human well-being: health synthesis. Island Press, Washington, D.C., USA.

Meine, C. 2004. Correction lines: essays on land, Leopold, and conservation. Island Press, Washington, D.C., USA.

Moreno-Mateos, D., M. E. Power, F. A. Comín, and R. Yockteng. 2012. Structural and functional loss in restored wetland ecosystems. PLoS Biology 10:e1001247. http://dx.doi.org/10.1371/ journal.pbio. 1001247

Myers, S. S., L. Gaffikin, C. D. Golden, R. S. Ostfeld, K. H. Redford, T. H. Ricketts, W. R. Turner, and S. A. Osofsky. 2013. Human health impacts of ecosystem alteration. Proceedings of the National Academy of Sciences 110:18753-18760. http://dx.doi. org/10.1073/pnas. 1218656110 
Neßhöver, C., J. Aronson, J. Blignaut, D. Lehr, A. Vakrou, and H. Wittmer. 2011. Investing in ecological infrastructure. Pages 401-448 in P. Ten Brink, editor. The economics of ecosystems and biodiversity in national and international policy making. Earthscan, London, USA.

Noji, E. K. 2005. Public health in the aftermath of disasters. BMJ 330:1379-1381. http://dx.doi.org/10.1136/bmj.330.7504.1379

Powe, N. A., and K. G. Willis. 2004. Mortality and morbidity benefits of air pollution $\left(\mathrm{SO}_{2}\right.$ and $\left.\mathrm{PM}_{10}\right)$ absorption attributable to woodland in Britain. Journal of Environmental Management 70:119-128. http://dx.doi.org/10.1016/j.jenvman.2003.11.003

Rapport, D. J., G. Böhm, D. Buckingham, J. Cairns Jr, R. Costanza, J. R. Karr, H. A. M. De Kruijf, R. Levins, A. J. McMichael, N. O. Nielsen, and W. G. Whitford. 1999. Ecosystem health: the concept, the ISEH, and the important tasks ahead. Ecosystem Health 5:82-90. http://dx.doi.org/10.1046/ j.1526-0992.1999.09913.x

Raven, P. H. 2016. Our world and Pope Francis' Encyclical, Laudato si'. Quarterly Review of Biology 91:247-260. http://dx. doi.org/10.1086/688094

Redford, K. H., S. S. Myers, T. H. Ricketts, and S. A. Osofsky. 2014. Human health as a judicious conservation opportunity. Conservation Biology 28:627-629. http://dx.doi.org/10.1111/ $\underline{\text { cobi. } 12290}$

Reed, J., L. Deakin, and T. Sunderland. 2015. What are 'integrated landscape approaches' and how effectively have they been implemented in the tropics: a systematic map protocol. Environmental Evidence 4:1-7. http://dx.doi.org/10.1186/2047-2382-4-2

Reed, J., J. Van Vianen, E. L. Deakin, J. Barlow, and T. Sunderland. 2016. Integrated landscape approaches to managing social and environmental issues in the tropics: learning from the past to guide the future. Global Change Biology 22:2540-2554. http://dx.doi.org/10.1111/gcb.13284

Society for Ecological Restoration (SER). 2004. The SER primer on ecological restoration. Science and Policy Working Group. SER, Washington, D.C., USA.

Suter II, G. W. 1993. A critique of ecosystem health concepts and indexes. Environmental Toxicology and Chemistry 12:1533-1539. http://dx.doi.org/10.1002/etc.5620120903

Taylor, L. H., S. M. Latham, and M. E. Woolhouse. 2001. Risk factors for human disease emergence. Philosophical Transactions of the Royal Society B Biological Sciences 356:983-989. http://dx. doi.org/10.1098/rstb.2001.0888

ten Brink, P., editor. 2011. The economics of ecosystems and biodiversity in national and international policymaking. Earthscan, London, UK.

Ulrich, R. S., R. F. Simons, B. D. Losito, E. Fiorito, M. A. Miles, and M. Zelson. 1991. Stress recovery during exposure to natural and urban environments. Journal of Environmental Psychology 11:201-230. http://dx.doi.org/10.1016/S0272-4944(05)80184-7

United Nations (U.N.). 2015. Goal 15: sustainably manage forests, combat desertification, halt and reverse land degradation, halt biodiversity loss. UN, New York, New York, USA.
United Nations Convention to Combat Desertification (UNCCD). 2015. Land matters for climate: reducing the gap and approaching the target. UNCCD, Bonn, Germany.

van den Bosch, M. A., and M. H. Depledge. 2015. Healthy people with nature in mind. BMC Public Health 15:1232. http://dx. doi. org/10.1186/s12889-015-2574-8

Wackernagel, M., and W. E. Rees. 1997. Perceptual and structural barriers to investing in natural capital: economics from an ecological footprint perspective. Ecological Economics 20:3-24. http://dx.doi.org/10.1016/S0921-8009(96)00077-8

Walker, B. 2001. Ecosystems and immune systems: useful analogy or stretching a metaphor? Conservation Ecology 5(1):16. https:// doi.org/10.5751/ES-00231-050116

Whitmee, S., A. Haines, C. Beyrer, F. Boltz, A. G. Capon, B. F. de Souza Dias, A. Ezeh, H. Frumkin, P. Gong, P. Head, et al. 2015. Safeguarding human health in the Anthropocene epoch: report of The Rockefeller Foundation-Lancet Commission on planetary health. Lancet 386:1973-2028. http://dx.doi.org/10.1016/ $\underline{\text { S0140-6736(15)60901-1 }}$

Wiens, J. A., G. D. Hayward, H. D. Safford, and C. M. Giffen. 2012. Historical environmental variation in conservation and natural resource management. Wiley-Blackwell, Chichester, UK. http://dx.doi.org/10.1002/9781118329726

Woodworth, P. 2013. Our once and future planet: restoring the world in the climate change century. University of Chicago Press, Chicago, Illinois, USA. http://dx.doi.org/10.7208/ chicago/9780226081465.001.0001

World Health Organization (WHO). 1948. Preamble to the Constitution of the World Health Organization as adopted by the International Health Conference, New York, 19-22 June, 1946; signed on 22 July 1946 by the representatives of 61 States (Official Records of the World Health Organization, no. 2, p. 100) and entered into force on 7 April 1948. WHO, Geneva, Switzerland.

World Health Organization (WHO). 2015. Connecting global priorities: biodiversity and human health: a state of knowledge review. WHO, Geneva, Switzerland. 